\title{
BONEKA SEBAGAI ALAT PEDAGOGI DALAM PERKEMBANGAN SOSIAL DAN EMOSI KANAK-KANAK PRASEKOLAH
}

\author{
Puppets as Pedagogical Tools in Social Development and Emotion of Preschool Children
}

Loy Chee Luen

Fakulti Pembangunan Manusia, Universiti Pendidikan Sultan Idris

35900 Tanjong Malim, Perak.

loy.cl@fppm.upsi.edu.my

\begin{abstract}
ABSTRAK
Boneka sebagai alat pedagogi dapat membantu perkembangan kanak-kanak dari segi sosial dan emosi. Penyelidikan ini dilaksanakan untuk mengenal pasti persepsi guru terhadap penggunaan boneka dalam perkembangan sosial dan emosi kanak-kanak di prasekolah. Sampel kajian terdiri daripada 100 guru prasekolah dari Kementerian Pendidikan Malaysia (KPM) dan swasta di sekitar Seremban, Kuala Lumpur dan Selangor. Data-data penyelidikan diperoleh melalui soal selidik dan diproses menggunakan Independent Samples T-test dan ANOVA Satu Hala. Keputusan penyelidikan telah mencapai hipotesis penyelidikan iaitu tidak terdapat perbezaan yang signifikan antara persepsi guru prasekolah terhadap penggunaan boneka sebagai alat bantu mengajar dalam perkembangan sosial dan emosi kanak-kanak berdasarkan status prasekolah dan tempoh mengajar guru di prasekolah. Ini menunjukkan guru prasekolah mempunyai persepsi yang positif terhadap penggunaan boneka dalam perkembangan sosial dan emosi kanak-kanak.
\end{abstract}

Kata Kunci: boneka, pedagogi, perkembangan kanak-kanak, sosial, emosi

\begin{abstract}
Puppets as a pedagogical tools helps to improve children's development in social and emotion areas. The purpose of the study is to focus on teacher's perception in the usage of puppets as a teaching tool in enhancing preschoolers social and emotion development. 100 preschool teachers were selected from the Ministry of Education (KPM) and private preschool around Seremban, Kuala Lumpur and Selangor. The research data were collected through questionnaires and were analyzed using Independent Samples T-test and One-Way ANOVA. The findings of the study supported the hypotheses that perception of preschool teacher according to the status of preschool and experiences teacher teaching at preschool were not significant. Result showed that preschool teachers have positive perception towards the usage of puppets in supporting children's social and emotion development.
\end{abstract}

Keywords: puppets, pedagogical, improve children's development, social, emotion

\section{PENGENALAN}

Boneka sebagai alat pedagogi mempunyai daya tarikan yang istimewa dalam pembelajaran kanak-kanak. Boneka diperbuat dalam pelbagai bentuk dan rupa seperti manusia, binatang dan tumbuh-tumbuhan boleh digunakan dalam aktiviti bercerita bersama boneka dan persembahan boneka. Aktiviti boneka dapat merangsang pembelajaran kanak-kanak peringkat prasekolah. Aktiviti boneka dapat menggalakkan penglibatan kanak-kanak dalam proses pedagogi. Boneka dapat menarik minat dan perhatian kanak-kanak terhadap pengajaran yang disampaikan oleh guru. Boneka membantu menghidupkan suasana pembelajaran yang lebih menyeronokkan dan seterusnya menimbulkan motivasi kepada pembelajaran kanak-kanak. Boneka boleh 
digabungjalinkan dalam pembelajaran kanak-kanak dan seterusnya membantu perkembangan sosial dan emosi mereka (McLain, 2006; Kirby, 2010; Mirella, 2012; Loy et al., 2017).

\section{TINJAUAN LITERATUR}

Perkembangan sosial dan emosi kanak-kanak sangat penting kerana ia menjadi asas kepada imej kendiri seseorang kanak-kanak. Teori perkembangan psikososial yang diperkenalkan oleh Erikson (1963) menyatakan bahawa faktor sosial dan emosi mempengaruhi perkembangan seseorang kanak-kanak terutamanya dari segi imej kendiri. Perluahan emosi dan hubungan sosial seseorang kanak-kanak dengan kanak-kanak lain atau orang dewasa adalah penting untuk mempamerkan imej kendiri seseorang kanak-kanak tersebut.

Kajian Deniger (1990) melibatkan sekumpulan kanak-kanak bermain bersama boneka di dalam bilik darjah. Melalui pemerhatian yang dijalankan oleh pengkaji, didapati terdapat perubahan sikap kanak-kanak daripada aspek sosial dan emosi yang jelas. Kajian ini membuktikan bahawa boneka dapat membantu perkembangan sosial dan emosi kanak-kanak dalam aktiviti bermain. Kajian yang dilaksanakan oleh Gronna et al. (1999) menyatakan bahawa aktiviti boneka yang dilaksanakan secara berkumpulan dapat menggalakkan interaksi sosial kanak-kanak. Dalam kajian ini mendapati bahawa kanak-kanak yang terlibat bekerjasama, berbincang dan menyelesaikan masalah dalam aktiviti boneka. Kajian Loy (2011) juga mendapati bahawa projek membina boneka, projek membina pentas boneka, projek perwatakan dan emosi, projek muzik dan pergerakan, projek pendahuluan dan perkembangan cerita, projek konflik dan pengakhiran cerita, projek latihan persembahan, projek persembahan dan projek menonton semula persembahan yang dilaksanakan untuk kanak-kanak dapat meningkatkan kemahiran sosial dan emosi mereka.

\section{Boneka dalam perkembangan sosial kanak-kanak}

Perkembangan sosial kanak-kanak melibatkan proses sosialisasi sepanjang aktiviti boneka yang dilaksanakan secara pasangan atau berkumpulan. Kanak-kanak perlu melakukan penyesuaian sosial dalam persekitaran pembelajaran yang menggunakan boneka sebagai alat pedagogi. Aktiviti boneka yang dilaksanakan dalam bilik darjah membolehkan kanak-kanak mempelajari tingkah laku sosial. Aktiviti boneka dilaksanakan secara pasangan atau berkumpulan memberi peluang kepada kanak-kanak untuk bekerja secara kolaboratif. Kanakkanak yang terlibat dalam aktiviti boneka dengan kanak-kanak lain akan mendapat tahu bahawa setiap individu mempunyai pandangan yang berbeza-beza. Mereka dikehendaki belajar bertolak ansur, saling hormat menghormati dan membina idea bersama-sama dan semasa aktiviti boneka (Deniger, 1990; Berk, 2006; Beaty, 2014; Loy, 2011).

Dalam penyelidikan ini, aktiviti boneka membantu membina kemahiran sosial kanak-kanak dengan menceritakan perasaan orang lain, menerima pandangan orang lain dan menghormati hak orang lain. Aktiviti boneka membantu mengekalkan penglibatan kanak-kanak dalam aktiviti kumpulan, mewujudkan kerjasama dan perasaan saling mempercayai antara kanak-kanak serta berinteraksi dengan rakan-rakan sebaya melalui persembahan dan aktiviti membuat boneka. 


\section{Boneka dalam perkembangan emosi kanak-kanak}

Emosi merupakan perasaan dalam tingkah laku kanak-kanak. Emosi kanak-kanak merangkumi emosi yang positif dan negatif. Emosi yang positif merujuk kepada rasa gembira dan seronok. Emosi yang negatif merujuk kepada emosi yang mempunyai nada yang negatif seperti marah, sedih dan takut. Kedua-dua jenis emosi ini dapat disampaikan menerusi aktiviti boneka. Aktiviti boneka dapat membantu perkembangan emosi kanakkanak. Menerusi aktiviti boneka, seseorang kanak-kanak dapat memahami dan menguruskan emosi sendiri dan seterusnya mencapai emosi yang positif. Kebolehan menguruskan emosi membantu kanak-kanak membina keyakinan diri, semangat berdikari dan sikap positif terhadap pembelajaran. Menerusi aktiviti boneka yang dilaksanakan oleh guru dalam bilik darjah, kanak-kanak dapat mengenali emosi sendiri secara mendalam (Deniger, 1990; Berk, 2006; Beaty, 2014; Loy, 2011).

Dalam penyelidikan ini, aspek yang ditinjau ialah persembahan boneka membantu kanakkanak membina kemahiran emosi untuk memahami diri dan memahami orang lain. Persembahan boneka membantu kanak-kanak mencapai emosi positif dan menunjukkan sifat positif. Kanak-kanak dapat meluahkan perasaan mereka dalam persembahan boneka. Kanakkanak yang malu lebih berani bersuara semasa memanipulasikan boneka manakala kanak-kanak yang agresif dapat mengawal diri semasa memanipulasikan boneka.

\section{REKA BENTUK KAJIAN}

Sampel kajian terdiri daripada 100 guru prasekolah dari Kementerian Pendidikan Malaysia (KPM) dan swasta di sekitar Seremban, Kuala Lumpur dan Selangor. Kajian ini berbentuk kuantitatif. Data-data penyelidikan diperoleh melalui soal selidik dan diproses menggunakan Independent Samples T-test dan ANOVA Satu Hala.

\section{OBJEKTIF KAJIAN}

Kajian ini ingin melihat persepsi guru prasekolah tentang boneka sebagai satu alat pedagogi yang dapat mengembangkan sosial dan emosi kanak-kanak prasekolah. Hal ini kerana guru prasekolah merupakan individu yang paling dekat dengan kanak-kanak prasekolah dan mereka dapat melihat perkembangan setiap kanak-kanak itu melalui setiap aktiviti yang dijalankan.

Secara khususnya tujuan kajian ini adalah untuk;

i. mengetahui persepsi guru terhadap penggunaan boneka sebagai alat pedagogi dalammembantu perkembangan kanak-kanak dari segi sosial dan emosi.

ii. melihat sama ada terdapat perbezaan atau persamaaan antara guru prasekolah KPM dan guru prasekolah swasta terhadap penggunaan boneka sebagai alat pedagogi dalam membantu perkembangan kanak-kanak dari segi sosial dan emosi.

iii. melihat sama ada terdapat perbezaan atau persamaaan berdasarkan tempoh pengalaman mengajar guru terhadap penggunaan boneka sebagai alat pedagogi dalam membantu perkembangan kanak-kanak dari segi sosial dan emosi. 


\section{Persoalan kajian}

\section{Soalan kajian 1}

Apakah persepsi guru prasekolah terhadap penggunaan boneka sebagai alat pedagogi dalam membantu perkembangan kanak-kanak dari segi sosial dan emosi?

\section{Soalan kajian 2}

Adakah guru prasekolah KPM dan guru prasekolah swasta mempunyai persepsi yang berbeza terhadap penggunaan boneka sebagai alat pedagogi dalam membantu perkembangan kanakkanak dari segi sosial dan emosi?

\section{Soalan kajian 3}

Adakah terdapat perbezaan persepsi antara guru prasekolah terhadap penggunaan boneka sebagai alat pedagogi dalam membantu perkembangan kanak-kanak dari segi sosial dan emosi berdasarkan tempoh pengalaman mengajar mereka di prasekolah?

\section{Hipotesis kajian}

Berikut ialah hipotesis yang dibina untuk menjawab soalan kajian 2.

Hipotesis penyelidikan 1 menyatakan tidak terdapat perbezaan yang signifikan antara persepsi guru prasekolah KPM dengan guru prasekolah swasta terhadap penggunaan boneka sebagai alat pedagogi dalam membantu perkembangan sosial kanak-kanak.

Hipotesis penyelidikan 2 menyatakan tidak terdapat perbezaan yang signifikan antara persepsi guru prasekolah KPM dengan guru prasekolah swasta terhadap penggunaan boneka sebagai alat pedagogi dalam membantu perkembangan emosi kanak-kanak.

Berikut ialah hipotesis yang dibina untuk menjawab soalan kajian 3.

Hipotesis penyelidikan 3 menyatakan tidak terdapat perbezaan yang signifikan antara persepsi guru prasekolah terhadap penggunaan boneka sebagai alat pedagogi dalam membantu perkembangan kanak-kanak dari segi sosial berdasarkan tempoh pengalaman mengajar mereka.

Hipotesis penyelidikan 4 menyatakan tidak terdapat perbezaan yang signifikan antara persepsi guru prasekolah terhadap penggunaan boneka sebagai alat pedagogi dalam membantu perkembangan kanak-kanak dari segi emosi berdasarkan tempoh pengalaman mengajar mereka.

\section{DAPATAN KAJIAN}

\section{Persepsi guru prasekolah terhadap boneka sebagai alat pedagogi yang dapat membantu perkembangan sosial dan emosi kanak-kanak}

Untuk menjawab soalan kajian 1, analisis deskriptif digunakan bertujuan untuk mengetahui persepsi guru terhadap penggunaan boneka sebagai alat pedagogi dalam membantu perkembangan kanak-kanak dari segi sosial dan emosi. 


\section{Perkembangan sosial}

Berdasarkan kepada Jadual 1 di bawah, sejumlah 16 orang (16\%) responden sangat setuju dengan kenyataan item 1. Responden yang setuju dengan kenyataan ini seramai 70 orang (70\%) manakala 14 orang (14\%) responden pula tidak pasti dengan kenyataan ini. boneka sebagai alat bantu mengajar dapat membantu perkembangan bahasa kanak-kanak. Boleh dikatakan bahawa peratus yang setuju atau lebih daripada setuju adalah $86 \%$ (iaitu $70 \%$ setuju dan $16 \%$ sangat setuju). Maka, ini menunjukkan bahawa majoriti daripada responden adalah bersetuju dengan item 1.

Bagi kenyataan item 2, 14 orang (14\%) responden sangat setuju manakala seramai 65 orang (65\%) responden setuju dengan kenyataan ini. 17 orang (17\%) responden tidak pasti dan terdapat 4 orang (4\%) responden tidak setuju dengan kenyataan ini. Boleh dikatakan bahawa peratus yang setuju atau lebih daripada setuju adalah 79\% (iaitu 65\% setuju dan 14\% sangat setuju). Maka, ini menunjukkan bahawa majoriti daripada responden adalah bersetuju dengan item 2.

Seramai 22 orang (22\%) responden sangat setuju dengan kenyataan item 3. Didapati 61 orang $(61 \%)$ responden setuju dengan kenyataan ini. 13 orang (13\%) responden tidak pasti dan 4 orang (4\%) lagi responden tidak bersetuju dengan kenyataan ini. Boleh dikatakan bahawa peratus yang setuju atau lebih daripada setuju adalah $83 \%$ (iaitu $61 \%$ setuju dan $22 \%$ sangat setuju). Maka, ini menunjukkan bahawa majoriti daripada responden adalah bersetuju dengan item 3.

Terdapat 21 orang $(21 \%)$ responden sangat setuju dengan kenyataaan item 4 . Responden yang setuju pula ialah 65 orang (65\%). 9 orang (9\%) responden tidak pasti dan 5 orang (5\%) responden tidak setuju dengan kenyataan ini. Boleh dikatakan bahawa peratus yang setuju atau lebih daripada setuju adalah $86 \%$ (iaitu $65 \%$ setuju dan $21 \%$ sangat setuju). Maka, ini menunjukkan bahawa majoriti daripada responden adalah bersetuju dengan item 4 .

Bagi kenyataan item 5, seramai 23 orang (23\%) responden yang sangat setuju. Sebahagian besar iaitu 64 orang (64\%) responden setuju dengan kenyataan ini. 12 orang (12\%) tidak pasti dan hanya seorang $(1 \%)$ responden yang tidak bersetuju dengan kenyataan item ini. Boleh dikatakan bahawa peratus yang setuju atau lebih daripada setuju adalah $87 \%$ (iaitu $64 \%$ setuju dan 23\% sangat setuju). Maka, ini menunjukkan bahawa majoriti daripada responden adalah bersetuju dengan item 5 .

Seramai 26 orang (26\%) responden sangat setuju dengan kenyataan item 6 ini. Terdapat 63 orang $(63 \%)$ responden yang setuju kenyataan ini. 7 orang $(7 \%)$ responden tidak pasti dan 2 orang $(2 \%)$ responden tidak setuju dengan kenyataan ini. Boleh dikatakan bahawa peratus yang setuju atau lebih daripada setuju adalah $89 \%$ (iaitu $63 \%$ setuju dan $26 \%$ sangat setuju). Maka, ini menunjukkan bahawa majoriti daripada responden adalah bersetuju dengan item 6 .

Dapatan ini menunjukkan bahawa boneka sebagai alat pedagogi dapat membantu perkembangan sosial kanak-kanak di prasekolah berdasarkan tahap persepsi guru dalam kajian ini. 
Jadual 1: Keputusan kekerapan dan peratusan persepsi guru terhadap boneka sebagai alat pedagogi dalam membantu perkembangan sosial kanak-kanak

\begin{tabular}{|c|c|c|c|c|}
\hline Item & Kenyataan & Pilihan & $\begin{array}{c}\text { Kekerapan } \\
\mathrm{N}=100\end{array}$ & $\begin{array}{c}\text { Peratus } \\
(\%)\end{array}$ \\
\hline 1 & $\begin{array}{l}\text { Aktiviti boneka membantu } \\
\text { membina kemahiran sosial kanak- } \\
\text { kanak dengan menceritakan } \\
\text { perasaan orang lain. }\end{array}$ & $\begin{array}{l}\text { Tidak setuju } \\
\text { Tidak pasti } \\
\text { Setuju } \\
\text { Sangat setuju }\end{array}$ & $\begin{array}{c}0 \\
14 \\
70 \\
16\end{array}$ & $\begin{array}{c}0 \\
14 \\
70 \\
16\end{array}$ \\
\hline 2 & $\begin{array}{l}\text { Aktiviti boneka membantu } \\
\text { membina kemahiran sosial kanak- } \\
\text { kanak dengan menerima } \\
\text { pandangan orang lain. }\end{array}$ & $\begin{array}{l}\text { Tidak setuju } \\
\text { Tidak pasti } \\
\text { Setuju } \\
\text { Sangat setuju }\end{array}$ & $\begin{array}{l}4 \\
17 \\
65 \\
14\end{array}$ & $\begin{array}{c}4 \\
17 \\
65 \\
14 \\
\end{array}$ \\
\hline 3 & $\begin{array}{l}\text { Aktiviti boneka membantu } \\
\text { membina kemahiran sosial kanak- } \\
\text { kanak dengan menghormati hak } \\
\text { orang lain. }\end{array}$ & $\begin{array}{l}\text { Tidak setuju } \\
\text { Tidak pasti } \\
\text { Setuju } \\
\text { Sangat setuju }\end{array}$ & $\begin{array}{c}4 \\
13 \\
61 \\
22 \\
\end{array}$ & $\begin{array}{c}4 \\
13 \\
61 \\
22 \\
\end{array}$ \\
\hline 4 & $\begin{array}{l}\text { Aktiviti boneka dapat membantu } \\
\text { mengekalkan penglibatan kanak- } \\
\text { kanak dalam aktiviti kumpulan. }\end{array}$ & $\begin{array}{l}\text { Tidak setuju } \\
\text { Tidak pasti } \\
\text { Setuju } \\
\text { Sangat setuju }\end{array}$ & $\begin{array}{c}5 \\
9 \\
65 \\
21\end{array}$ & $\begin{array}{c}5 \\
9 \\
65 \\
21\end{array}$ \\
\hline 5 & $\begin{array}{l}\text { Aktiviti membuat boneka secara } \\
\text { berkumpulan mewujudkan } \\
\text { kerjasama dan perasaan saling } \\
\text { mempercayai antara kanak-kanak. }\end{array}$ & $\begin{array}{l}\text { Sangat tidak setuju } \\
\text { Tidak setuju } \\
\text { Tidak pasti } \\
\text { Setuju } \\
\text { Sangat setuju } \\
\end{array}$ & $\begin{array}{c}1 \\
12 \\
64 \\
23 \\
\end{array}$ & $\begin{array}{c}1 \\
12 \\
64 \\
23 \\
\end{array}$ \\
\hline 6 & $\begin{array}{l}\text { Kanak-kanak dapat berinteraksi } \\
\text { dengan rakan-rakan sebaya } \\
\text { melalui persembahan dan aktiviti } \\
\text { membuat boneka. }\end{array}$ & $\begin{array}{l}\text { Tidak setuju } \\
\text { Tidak pasti } \\
\text { Setuju } \\
\text { Sangat setuju }\end{array}$ & $\begin{array}{c}2 \\
7 \\
63 \\
26\end{array}$ & $\begin{array}{c}2 \\
7 \\
63 \\
26 \\
\end{array}$ \\
\hline Jumlah & & & 100 & 100 \\
\hline
\end{tabular}

\section{Perkembangan emosi}

Daripada Jadual 2 berikut, didapati 13 orang (13\%) responden sangat setuju dengan kenyataan item 7. Seramai 69 orang (69\%) responden setuju dan 17 orang (17\%) responden tidak pasti dengan kenyataan ini. Bagi item ini, hanya seorang (1\%) sahaja responden tidak bersetuju. Boleh dikatakan bahawa peratus yang setuju atau lebih daripada setuju adalah $82 \%$ (iaitu 69\% setuju dan $13 \%$ sangat setuju). Maka, ini menunjukkan bahawa majoriti daripada responden adalah bersetuju dengan item 7 .

Seramai 11 orang (11\%) responden sangan setuju dengan kenyataan item 8. Sebahagian besar iaitu 64 orang $(64 \%)$ responden setuju dengan kenyataan ini. Terdapat 23 orang (23\%) responden tidak pasti dan 2 orang (2\%) responden yang tidak setuju dengan kenyataan ini. Boleh dikatakan bahawa peratus yang setuju atau lebih daripada setuju adalah $75 \%$ (iaitu $64 \%$ 
setuju dan $11 \%$ sangat setuju). Maka, ini menunjukkan bahawa majoriti daripada responden adalah bersetuju dengan item 8 .

Bagi item 9, seramai 9 orang (9\%) responden yang sangat setuju dengan kenyataan ini. Sebahagian besar iaitu 71 orang $(71 \%)$ responden yang setuju dengan kenyataan ini. 17 orang (17\%) responden tidak pasti dan 3 orang (3\%) responden yang tidak setuju dengan kenyataan ini. Boleh dikatakan bahawa peratus yang setuju atau lebih daripada setuju adalah $80 \%$ (iaitu $71 \%$ setuju dan 9\% sangat setuju). Maka, ini menunjukkan bahawa majoriti daripada responden adalah bersetuju dengan item 9 .

Terdapat 17 orang (17\%) responden yang sangat setuju dengan kenyataan item 10. Didapati 68 orang $(68 \%)$ responden setuju dengan kenyataan ini. Seramai 14 orang (14\%) responden tidak pasti dan hanya seorang (1\%) responden yang tidak bersetuju dengan kenyataan ini. Boleh dikatakan bahawa peratus yang setuju atau lebih daripada setuju adalah $85 \%$ (iaitu $68 \%$ setuju dan $17 \%$ sangat setuju). Maka, ini menunjukkan bahawa majoriti daripada responden adalah bersetuju dengan item 10 .

Sejumlah 16 orang (16\%) responden yang sangat setuju kenyataan item11. Seramai 57 orang $(57 \%)$ responden yang setuju dengan kenyataan ini. Terdapat 22 orang (22\%) responden tidak pasti kenyataan item ini. Terdapat 3 orang (3\%) responden tidak setuju dan 2 orang (2\%) responden lagi sangat tidak setuju dengan kenyataan ini. Boleh dikatakan bahawa peratus yang setuju atau lebih daripada setuju adalah $73 \%$ (iaitu 57\% setuju dan $16 \%$ sangat setuju). Maka, ini menunjukkan bahawa majoriti daripada responden adalah bersetuju dengan item 11 .

Bilangan responden yang sangat setuju dengan kenyataan item 12 ialah seramai 11 orang $(11 \%)$. 54 orang $(54 \%)$ responden setuju dengan kenyataan item ini. 23 orang (23\%) responden tidak pasti. 10 orang (10\%) responden tidak setuju dan 2 orang (2\%) responden sangat tidak setuju dengan kenyataan item ini. Boleh dikatakan bahawa peratus yang setuju atau lebih daripada setuju adalah $65 \%$ (iaitu 54\% setuju dan $11 \%$ sangat setuju). Maka, ini menunjukkan bahawa majoriti daripada responden adalah bersetuju dengan item 12 .

Dapatan ini menunujukkan bahawa boneka sebagai alat pedagogi dapat membantu perkembangan emosi kanak-kanak di prasekolah berdasarkan tahap persepsi guru dalam kajian ini.

Jadual 2: Keputusan kekerapan dan peratusan persepsi guru terhadap boneka sebagai alat pedagogi dalam membantu perkembangan emosi kanak-kanak

\begin{tabular}{cllcc}
\hline Item & \multicolumn{1}{c}{ Kenyataan } & \multicolumn{1}{c}{ Pilihan } & $\begin{array}{c}\text { Kekerapan } \\
\text { N=100 }\end{array}$ & $\begin{array}{c}\text { Peratus } \\
(\%)\end{array}$ \\
\hline \multirow{2}{*}{7} & Aktiviti boneka membantu kanak- & Sangat tidak setuju & 0 & 0 \\
& kanak membina kemahiran emosi & Tidak setuju & 1 & 1 \\
& untuk memahami diri. & Tidak pasti & 17 & 17 \\
& & Setuju & 69 & 69 \\
& & Sangat setuju & 13 & 13 \\
& & Sangat tidak setuju & 0 & 0 \\
\hline \multirow{2}{*}{8} & Aktiviti boneka membantu kanak- & Tidak setuju & 2 & 2 \\
& kanak membina kemahiran emosi & Tidak pasti & 23 & 23 \\
& untuk memahami orang lain. & Setuju & 64 & 64 \\
& & Sangat setuju & 11 & 11
\end{tabular}




\begin{tabular}{cllcc} 
& & Sangat tidak setuju & 0 & 0 \\
\hline \multirow{3}{*}{9} & Aktiviti boneka membantu kanak- & Tidak setuju & 3 & 3 \\
& kanak mencapai emosi positif dan & Tidak pasti & 17 & 17 \\
& menunjukkan sifat positif. & Setuju & 71 & 71 \\
& & Sangat setuju & 9 & 9 \\
& & Sangat tidak setuju & 0 & 0 \\
\hline \multirow{3}{*}{10} & Kanak-kanak dapat meluahkan & Tidak setuju & 1 & 1 \\
& perasaan mereka dalam aktiviti & Tidak pasti & 14 & 14 \\
& boneka. & Setuju & 68 & 68 \\
& & Sangat setuju & 17 & 17 \\
& & Sangat tidak setuju & 2 & 2 \\
\hline \multirow{3}{*}{11} & Kanak-kanak yang malu lebih & Tidak setuju & 3 & 3 \\
& berani bersuara semasa & Tidak pasti & 22 & 22 \\
& memanipulasikan boneka. & Setuju & 57 & 57 \\
& & Sangat setuju & 16 & 16 \\
& & Sangat tidak setuju & 2 & 2 \\
\hline \multirow{3}{*}{12} & Kanak-kanak yang agresif dapat & Tidak setuju & 10 & 10 \\
& mengawal diri semasa & Tidak pasti & 23 & 23 \\
& memanipulasikan boneka. & Setuju & 54 & 54 \\
& & Sangat setuju & 11 & 11 \\
\hline Jumlah & & & 100 & 100 \\
\hline
\end{tabular}

Persepsi guru prasekolah KPM dan guru prasekolah swasta terhadap boneka sebagai alat pedagogi yang dapat membantu perkembangan sosial dan emosi kanak-kanak

Untuk menjawab soalan kajian 2, Independent Sample T-test digunakan bertujuan untuk mengenal pasti sama ada terdapat perbezaan yang signifikan antara persepsi guru prasekolah KPM dan guru prasekolah swasta terhadap penggunaan boneka sebagai alat pedagogi dalam membantu perkembangan kanak-kanak dari segi sosial dan emosi.

\section{Hipotesis 1}

Hipotesis penyelidikan 1 dibina untuk mengenal pasti sama ada terdapat perbezaan yang signifikan tentang persepsi guru prasekolah KPM dengan guru prasekolah swasta terhadap penggunaan boneka sebagai alat pedagogi dalam membantu perkembangan kanak-kanak dari segi sosial.

Jadual 3 menunjukkan bahawa min kumpulan KPM ialah 24.23 dengan sisihan piawai 3.144 manakala kumpulan Swasta mempunyai min 24.16 dengan sisihan piawai 2.890. Keputusan ujian-t menunjukkan bahawa nilai $\mathrm{t}(98)=0.914$, adalah tidak signifikan kerana pada aras sinifikan 0.05. Ini bererti hipotesis nul diterima dan hipotesis alternatif ditolak. Keputusan ujian-t menunjukkan tiada perbezaan yang signifikan tentang persepsi guru prasekolah KPM dengan guru prasekolah swasta terhadap penggunaan boneka sebagai alat pedagogi dalam membantu perkembangan kanak-kanak dari segi sosial. 
Jadual 3: Keputusan ujian-t tentang persepsi guru prasekolah KPM dengan guru prasekolah swasta terhadap boneka sebagai pedagogi dalam perkembangan sosial kanak-kanak

\begin{tabular}{lcccccc}
\hline Status sekolah & $\mathrm{N}$ & Min & $\begin{array}{c}\text { SP } \\
(\text { Std.D })\end{array}$ & $\begin{array}{c}\mathrm{dk} \\
(d f)\end{array}$ & $t$ & Sig \\
\hline KPM & 62 & 24.23 & 3.144 & & & \\
Swasta & 38 & 24.16 & 2.890 & 98 & 0.914 & 0.588 \\
& & & & & & \\
\hline
\end{tabular}

$\mathrm{N}$ mewakili bilangan responden

* menandakan signifikan pada $\mathrm{p}<0.05$

\section{Hipotesis 2}

Hipotesis penyelidikan 2 dibina untuk mengenal pasti sama ada terdapat perbezaan yang signifikan tentang persepsi guru prasekolah KPM dengan guru prasekolah swasta terhadap penggunaan boneka sebagai alat pedagogi dalam membantu perkembangan kanak-kanak dari segi emosi.

Jadual 4 menunjukkan bahawa min kumpulan KPM ialah 22.84 dengan sisihan piawai 2.818 manakala kumpulan Swasta mempunyai min 23.50 dengan sisihan piawai 3.169. Keputusan ujian-t menunjukkan bahawa nilai $\mathrm{t}(98)=0.280$, adalah tidak signifikan kerana pada aras signifikan 0.05. Ini bererti hipotesis nul diterima dan hipotesis alternatif ditolak. Keputusan ujian-t menunjukkan tiada perbezaan yang signifikan tentang persepsi guru prasekolah KPM dengan guru prasekolah swasta terhadap penggunaan boneka sebagai alat pedagogi dalam membantu perkembangan kanak-kanak dari segi emosi.

Jadual 4: Keputusan ujian-t tentang persepsi guru prasekolah KPM dengan guru prasekolah swasta terhadap boneka sebagai pedagogi dalam perkembangan emosi kanak-kanak

\begin{tabular}{lcccccc}
\hline Status sekolah & $\mathrm{N}$ & Min & $\begin{array}{c}\text { SP } \\
(\text { Std.D })\end{array}$ & $\begin{array}{c}\text { dk } \\
(d f)\end{array}$ & $t$ & Sig \\
\hline KPM & 62 & 22.84 & 2.818 & & & \\
Swasta & 38 & 23.50 & 3.169 & 98 & 0.280 & 0.176 \\
& & & & & & \\
\hline
\end{tabular}

$\mathrm{N}$ mewakili bilangan responden

* menandakan signifikan pada $\mathrm{p}<0.05$

Persepsi antara guru prasekolah terhadap boneka sebagai alat pedagogi yang dapat membantu perkembangan sosial dan emosi kanak-kanak berdasarkan pengalaman mengajar mereka di prasekolah.

Untuk menjawab soalan kajian 3, teknik ANOVA satu hala digunakan bertujuan untuk mengenal pasti sama ada terdapat perbezaan yang signifikan antara persepsi guru-guru 
prasekolah mengikut tempoh pengalaman mengajar mereka di prasekolah iaitu 10 tahun ke bawah, 11-20 tahun dan 21 tahun ke atas terhadap penggunaan boneka sebagai alat pedagogi dalam membantu perkembangan kanak-kanak dari segi sosial dan emosi.

\section{Hipotesis 3}

Tidak terdapat perbezaan yang signifikan tentang persepsi guru prasekolah mengikut tempoh pengalaman mengajar mereka di prasekolah iaitu 10 tahun ke bawah, 11-20 tahun dan 21 tahun ke atas terhadap penggunaan boneka sebagai alat pedagogi dalam membantu perkembangan kanak-kanak dari segi sosial.

Keputusan menunjukkan bahawa tidak terdapat perbezaan yang signifikan antara persepsi guru prasekolah terhadap boneka sebagai alat pedagogi dalam perkembangan sosial kanak-kanak mengikut tempoh pengalaman mereka mengajar di prasekolah iaitu $\mathrm{F}(2,97)=$ $1.382, \mathrm{p}>0.05$. Oleh itu, kenyataan bagi hipotesis ini yang menyatakan bahawa tidak terdapat perbezaan yang signifikan dari segi persepsi terhadap boneka sebagai alat pedagogi dalam perkembangan sosial kanak-kanak antara tempoh pengalaman guru mengajar di prasekolah diterima. Jadual 5 di bawah menunjukkan hasil analisis hipotesis 3.

Jadual 5: Keputusan ANOVA sehala tentang persepsi guru prasekolah mengikut tempoh pengalaman mengajar di prasekolah terhadap boneka sebagai alat pedagogi dalam perkembangan sosial kanak-kanak

\begin{tabular}{lrrrrr}
\hline Pembolehubah & \multicolumn{1}{c}{$\begin{array}{c}\text { JKD } \\
\text { (Sum of Squares) }\end{array}$} & $\begin{array}{c}\mathrm{dk} \\
(d f)\end{array}$ & $\begin{array}{c}\text { MKD } \\
\text { (Mean Square) }\end{array}$ & $F$ & Sig \\
\hline Antara Kumpulan & 25.262 & 2 & 12.631 & & \\
Dalam Kumpulan & 886.737 & 97 & 9.142 & & 0.256 \\
Jumlah & 912.000 & 99 & & & \\
\hline
\end{tabular}

\section{Hipotesis 4}

Tidak terdapat perbezaan yang signifikan tentang persepsi guru prasekolah mengikut tempoh pengalaman mengajar mereka di prasekolah iaitu 10 tahun ke bawah, 11-20 tahun dan 21 tahun ke atas terhadap penggunaan boneka sebagai alat pedagogi dalam membantu perkembangan kanak-kanak dari segi emosi.

Keputusan menunjukkan bahawa tidak terdapat perbezaan yang signifikan antara persepsi guru prasekolah terhadap boneka sebagai alat pedagogi dalam perkembangan emosi kanak-kanak mengikut tempoh pengalaman mereka mengajar di prasekolah iaitu $\mathrm{F}(2,97)=$ $1.118, \mathrm{p}>0.05$. Oleh itu, kenyataan bagi hipotesis ini yang menyatakan bahawa tidak terdapat perbezaan yang signifikan dari segi persepsi terhadap boneka sebagai alat pedagogi dalam perkembangan emosi kanak-kanak antara tempoh pengalaman guru mengajar di prasekolah diterima. Jadual 6 di bawah menunjukkan hasil analisis hipotesis 4. 
Jadual 6: Keputusan ANOVA sehala tentang persepsi guru prasekolah mengikut tempoh pengalaman mengajar di prasekolah terhadap boneka sebagai pedagogi dalam perkembangan emosi kanak-kanak

\begin{tabular}{lrrrrr}
\hline Pembolehubah & \multicolumn{1}{c}{$\begin{array}{c}\text { JKD } \\
\text { (Sum of Squares) }\end{array}$} & $\begin{array}{c}\mathrm{dk} \\
(d f)\end{array}$ & $\begin{array}{c}\text { MKD } \\
\text { (Mean Square) }\end{array}$ & $F$ & Sig \\
\hline Antara Kumpulan & 19.515 & 2 & 9.757 & & \\
Dalam Kumpulan & 846.675 & 97 & 8.729 & 1.118 & 0.331 \\
$\quad$ Jumlah & 866.190 & 99 & & & \\
\hline
\end{tabular}

\section{RUMUSAN}

Hasil kajian menunjukan persepsi guru prasekolah terhadap boneka sebagai pedagogi dalam perkembangan sosial dan emosi kanak-kanak adalah positif. Berikut ialah keputusan-keputusan dalam kajian ini mengikut aspek;

\section{Aspek boneka dalam perkembangan sosial kanak-kanak}

a. Persepsi guru prasekolah keseluruhan

Bagi item 1 hingga 6, boleh dikatakan bahawa peratus yang setuju atau lebih daripada setuju adalah $85 \%$ (iaitu $64.7 \%$ setuju dan $20.3 \%$ sangat setuju). Maka, ini menunjukkan bahawa majoriti daripada responden adalah bersetuju bahawa boneka dapat membantu perkembangan sosial kanak-kanak. Dapat dirumuskan bahawa boneka sebagai alat pedagogi dapat membantu perkembangan sosial kanak-kanak di prasekolah berdasarkan persepsi guru.

b. Persepsi guru prasekolah KPM dan guru prasekolah swasta

Keputusan kajian menunjukkan tiada wujud perbezaan yang signifikan antara persepsi guru prasekolah KPM atau swasta dalam melihat boneka sebagai alat bantu mengajar untuk membantu perkembangan sosial kanak-kanak. Ini menunjukkan bahawa guru prasekolah KPM dan guru prasekolah swasta mempunyai persepsi yang sama terhadap boneka sebagai alat pedagogi dalam membantu perkembangan sosial kanak-kanak.

c. Persepsi guru prasekolah berdasarkan tempoh pengajaran di prasekolah

Persepsi guru prasekolah berdasarkan tempoh pengalaman mengajar mereka di prasekolah juga menunujukkan hasil kajian yang sama iaitu tidak terdapat perbezaan yang signifikan terhadap boneka sebagai alat pedagogi dalam membantu perkembangan sosial kanak-kanak. Ini menunjukkan bahawa guru yang baru mengajar dan guru yang lama mengajar mempunyai persepsi yang sama terhadap boneka sebagai alat pedagogi dalam membantu perkembangan sosial kanak-kanak.

Keputusan kajian ini adalah selaras dengan kajian Loy (2011), Deniger (1990) dan Gronna et al. (1999) yang menyatakan bahawa penggunaan boneka sebagai alat pedagogi dapat membantu perkembangan sosial kanak-kanak. 


\section{Aspek boneka dalam perkembangan emosi kanak-kanak}

\section{a. Persepsi guru prasekolah keseluruhan}

Bagi item 7 hingga 12, boleh dikatakan bahawa peratus yang setuju atau lebih daripada setuju adalah $76.6 \%$ (iaitu $63.8 \%$ setuju dan $12.8 \%$ sangat setuju). Maka, ini menunjukkan bahawa majoriti daripada responden adalah bersetuju bahawa boneka dapat membantu perkembangan emosi kanak-kanak. Dapat dirumuskan bahawa boneka sebagai alat pedagogi dapat membantu perkembangan emosi kanak-kanak di prasekolah berdasarkan persepsi guru.

\section{b. Persepsi guru prasekolah KPM dan guru prasekolah swasta}

Keputusan kajian menunjukkan tiada wujud perbezaan yang signifikan antara persepsi guru prasekolah KPM atau swasta dalam melihat boneka sebagai alat bantu mengajar untuk membantu perkembangan emosi kanak-kanak. Ini menunjukkan bahawa guru prasekolah KPM dan guru prasekolah swasta mempunyai persepsi yang sama terhadap boneka sebagai alat pedagogi dalam membantu perkembangan emosi kanak-kanak.

\section{c. Persepsi guru prasekolah berdasarkan tempoh pengajaran di prasekolah}

Persepsi guru prasekolah berdasarkan tempoh pengalaman mengajar mereka di prasekolah juga menunjukkan hasil kajian yang sama iaitu tidak terdapat perbezaan yang signifikan terhadap boneka sebagai alat bantu mengajar dalam membantu perkembangan emosi kanakkanak. Ini menunjukkan bahawa guru yang baru mengajar dan guru yang lama mengajar mempunyai persepsi yang sama terhadap boneka sebagai alat pedagogi dalam membantu perkembangan emosi kanak-kanak.

Keputusan kajian ini adalah selaras dengan kajian Loy (2011) dan Deniger (1990) yang menyatakan bahawa penggunaan boneka sebagai alat pedagogi dapat membantu perkembangan emosi kanak-kanak.

\section{RUJUKAN}

Beaty, J.J. (2014). Preschool appropriate practices: environment, curriculum and development. United States: Cengage Learning.

Berk, L.E. (2006). Child development. Boston: Person.

Deniger, M. M. (1990). An ethnographic study of the use of puppetry with a children's group. Tesis. Texas, University of Texas.

Erikson, E.H. (1963). Childhood and society. New York: W.W. Norton \& Company, Inc.

Gronna, S. S, Serna, L. A, Kennedy, C. H \& Prater, M. A. (1999). Promoting generalized social interaction using puppets and script training in an integrated preschool: A single-case study. Projek kajian tindakan. Saint Xavier University \& Sky Light Professional Development Field-Based Master's Program.

Kirby, L. M. (2010). Puppetry in the visual arts classroom. Disertasi. Ohio State University.

Loy Chee Luen. (2011). Boneka sebagai alat pedagogi dalam pengajaran kanak-kanak prasekolah. Tesis. Fakulti Pendidikan, Universiti Malaya.

Loy Chee Luen, Nordin Mamat, Nor Mashitah Mohd Radzi \& Sopia Md Yassin. (2017). Observation instrument to evaluate early childhood educator's teaching strategies using creative arts. International Journal of Academic Research in Business and Social Sciences, 7(4), 870-880.

McLain, S. (2006). Exploration of theatre and using puppets in the classroom: a study of creativity in teaching. Tesis. The University of Montana.

Mirella, F.A. (2012). The puppet's communicative potential as a mediating tool in preschool education. IJEC, 44,171-184. 